\title{
Надання допомоги при інсульті за Програмою медичних гарантій: виклики та досягнення
}

14 квітня 2021 р. у Києві відбулася пресконференція «Надання допомоги при інсульті за Програмою медичних гарантій: виклики та досягнення», в ході якої було обговорено перші підсумки роботи Програми медичних гарантій в частині допомоги пацієнтам 3 гострим мозковим інсультом.

Гострий мозковий інсульт $є$ однією із найбільш болючих проблем для суспільства. Його наслідки створюють несприятливу соціально-економічну та медичну проблему. Щороку близько 130 тис. громадян України стикаються із цією патологією, що призводить до підвищення дочасної смертності $(18,6-19,8 \%)$ та розвитку стійких довготривалих інвалідизуючих ускладнень у 43,1\% тих, хто одужав. За статистичними даними, інсульт входить у трійку захворювань, які $\epsilon$ лідерами причин розвитку як дочасної смертності, так і формування інвалідизуючих ускладнень (хвороби системи кровообігу, злоякісні новоутворення та зовнішні причини - 67,4; 13,4 і 5,4\% відповідно і сукупно - 80-85\% усіх випадків смерті). Водночас розвиток сучасних технологій дозволяє підвищити якість лікування та значно зменшити тягар фатальних ускладнень. Саме тому надання допомоги хворим з інсультом стало пріоритетом для держави.

Надання медичної допомоги при гострому мозковому інсульті (ГМІ) входить в Програму медичних гарантій та оплачується Національною службою здоров'я України (НСЗУ), тобто $є$ безкоштовним для пацієнтів. Для цього держава за лікування пацієнтів з ГМІ за 9 міс 2020 р. перерахувала у медичні заклади, які надають таку допомогу та уклали угоду з НСЗУ, 1,36 млрд грн. Враховуючи отримані попередні результати запровадженої Програми на 2021 р. для оплати медичної допомоги при інсульті заплановано витрати у розмірі 2,57 млрд грн.

Такі угоди з надання пакету послуг хворим з інсультом у 2020 p. підписали 192 медичних заклади країни. Угода перш за все була законтрактована із тими лікарнями, які відповідають вимогам Міністерства охорони здоров'я (МОЗ) України та НСЗУ для надання пакету медичної допомоги категорії хворих з ГMІ, який гарантує цілодобовий (24/7) прийом хворих, забезпечення комп'ютерної (КТ) та магнітно-резонансної томографії (МРТ), цілодобову доступність невролога/нейрохірурга та анестезіолога із функціонуванням відділення інтенсивної терапії, лабораторії.

За наказом МОЗ України, усіх пацієнтів з ознаками інсульту зобов'язані у екстреному порядку транспортувати до лікарень, які уклали угоду та мають договір із НСЗУ для надання пакету спеціалізованої допомоги хворим з ГМІ. При цьому суворо регламентовано час надання такої допомоги, а також перелік першочергових діагностичних заходів у першу годину після доправлення у лікарню: обов'язкове КТ- або МРТ-обстеження.

Програма медичних гарантій в частині допомоги пацієнтам з ГМІ покриває усе необхідне лікування, діагностику та реабілітацію у гострий період, а також проведення тромболізису — введення спеціального лікарського засобу (тромболітику), який розчиняє тромб. Наразі програмою передбачено надання безоплатної гарантованої допомоги хворим на ГMІ, а також формування розгалуженої мережі реперфузійних інсультних центрів, впровадження та цілодобове функціонування яких дасть змогу надавати невідкладну допомогу хворим у перші години ГMІ, знизити летальність і захворюваність. Запропонована стратегія $\epsilon$ складовою Європейського плану дій боротьби з інсультом (European Stroke Action Plan — ESAP) на період 2018-2030 pp.

Запрошені спікери детально і покроково обговорили досягнення та проблеми надання допомоги хворим з ГМІ за час дії Програми медичних гарантій, які варті суспільної уваги.
Сергій Московко, завідувач кафедри нервових хвороб Вінницького національного медичного університету ім. М.І. Пирогова, куратор обласного інсультного центру, національний координатор «lніціативи Angels» в Україні, президент ГО «Українське товариство інсультної медицини», зазначив: «Ми оцінюємо результати першого року роботи Програми медичних гарантій в частині допомоги пачієнтам з гострим мозковим інсультом позитивно: нам вдалося почати реформування та виявити помилки, однак попереду ще дуже багато роботи. Ми вже побачили покращення у маршруті пацієнта, доправлення хворих до спеціалізованих лікарень та надання правильної діагностики. Вчасна кваліфікована медична допомога - це критично важливо, іче перший крок до якісного лікування інсульту. Немає нічого важчого, ніж початок, і ми якраз на початку прочесу створення всеохоплюючої допомоги пачієнтам з інсультом в Україні».

Ірина Садов'як, перший заступник міністра охорони здоров'я України, підкреслила: «МОЗ посилено прачювало у напрямку покращення надання медичної допомоги пачієнтам з інсультом. Ми вважаємо, що у 2020 р. було зроблено ряд важливих кроків для цього, зокрема і впровадження Програми медичних гарантій в частині допомоги пацієнтам з гострим мозковим інсультом. Впродовж року ми підвищили тариф та підходи до оплати лікарням, які лікують пачієнтів з інсультом. МОЗ видало наказ, який зобов'язує здійснювати транспортну госпіталізачію хворих з гострим мозковим інсультом за певними регламентованими вимогами до відділень екстреної медичної допомоги. Вже сьогодні можемо сказати, що завдяки цим крокам смертність від інсульту узакладах, які законтрактувалися з НСЗУ та відповідали усім вимогам надання такої допомоги, смертність знизилася до 12\%. У 2021 р. плануємо підвищити вимоги до лікарень, які хочуть надавати допомогу пачієнтам з гострим мозковим інсультом. Наразі готується положення про інсультні центри та інсультні блоки, де будуть чітко викладені вимоги та функції цих медичних підрозділів/відділень».

Олександр Данилюк, керівник експертної групи з питань розвитку екстреної допомоги Директорату медичного забезпечення МОЗ України, зазначив: «Перебудова маршрутів госпіталізачії пацієнтів з гострим мозковим інсультом відбувається небездоганно. Система надання допомоги при чій патології працювала за одними правилами, зараз чі правила змінилися. Для того щоб вона почала прачювати ідеально, потрібні час для навчання персоналу, зміна підходів до тактики лікування та до маршруту пацієнта. Станом на лютий 2021 р. лише 70\% пацієнтів з інсультом було госпіталізовано до спеціалізованих лікарень, які відповідають усім вимогам до таких закладів. Аби стимулювати впровадження необхідних вимог і таким чином підвищити якість допомоги у всіх без винятку лікувальних закладах, НСЗУ у 2021 р. ввела фінансові винагороди для екстреної медичної допомоги, аби стимулювати персонал виконувати затверджений МОЗ маршрут пачієнта».

Оксана Сухорукова, директор департаменту моніторингу НСЗУ, повідомила: «За даними електронної системи моніторингу, за 9 міс 2020 р. сталося 81 тис. випадків інсульту. Пачієнти з підозрою на гострий мозковий інсульт були доправлені у 730 медичних закладів у визначений часовий проміжок. При цьому ті, які були госпіталізовані у спеціалізовані відділення (більшість паці- 
єнтів, 64 тис.), законтрактовані з НСЗу, демонстрували прогрес у зниженні госпітальної смертності, яка порівняно із непрофільними закладами знизилася на 6,2\%. Це дозволило у $90 \%$ пацієнтів виконати КТ-обстеження для підтвердження чи виключення діагнозу (ішемічний інсульт) та провести тромболітичне лікування у 5,7\% пачієнтів з ішемічним інсультом відповідно до клінічних обставин. Це лише доводить необхідність подальшого розвитку відділень спеціалізованої допомоги. Однак залишається проблема реабілітації иих хворих. Лише $53 \%$ пацієнтів отримали ії на госпітальному етаni. 3 метою подальшого вдосконалення розвитку спеціалізованої допомоги хворим з гострим мозковим інсультом МОЗ буде суворо відслідковувати наявність матеріально-технічної бази при укладенні угод із лікарнями. Станом на 2021 р. 259 медичних закладів подали заяви на укладання договорів з надання медичної допомоги хворим з гострим мозковим інсультом. Однак детальний розгляд заяв дозволив із цього списку виключити 34 лікувальні заклади, оскільки вони не відповідають базовим вимогам».

Дмитро Самофалов, директор Південного міжрегіонального департаменту НСЗУ, наголосив: «Якщо пацієнту з інсультом не проведено КT- чи МРT-обстеження на етаnі екстреної госпіталізації, такі хворі не потрапляють до переліку осіб, яким гарантована допомога у пакеті допомоги при гострому мозковому інсульті, яка гарантована НСЗу. Таким чином, ми не укладаємо договори з лікарнями, які не здатні забезпечити відповідну діагностичну програму, надати лікувальну допомогу відповідно до розробленого протоколу, визначеного вимогами НСЗУ. Наразі підкреслюю, що уся діагностична та лікувальна допомога передбачена протоколом ї̈ надання хворим з гострим мозковим інсультом, $\epsilon$ безкоштовною! А всі вимоги персоналу закладу на додаткові витрату з боку рідних та близьких хворого $є$ неправомірними».

Дмитро Лебединець, керівник Інсультного центру клінічної лікарні «Феофанія» ДУС, м. Київ, член робочих груп МОЗ України та НСЗУ з питань інсульту, співзасновник та член правління
ГО «Українське товариство інсультної медицини», зауважив: «Якщо у 2019 р. в Україні було 128-130 тис. госпіталізованих з приводу інсультів, то в 2020 р. чей показник становить близько 125 тис. випадків. Також за рік на понад $1 \%$ підвищилася госпітальна летальність від інсульту - з 18,6 до 19,8\%. Хоча вона залишається значно нижчою, близько 12\%, узакладах, які надають спеціалізовану медичну допомогу і відповідають вимогам НСзу. Серед нагальних проблем, без вирішення яких не можливе подальше вдосконалення допомоги, є кадровий «голод». На че фінансові витрати не передбачені. Це питання, яке потребує нагального вирішення».

Наталія Скиба, маркетинг-менеджер компанії «Берінгер Інгельхайм», повідомила: «Компанія «Берінгер Інгельхайм» як сочіально відповідальний бізнес допомагає долати виклики, які пов'язані з інсультом. Наша мета - сприяти зниженню рівня смертності та інвалідизації після інсульту, щоб люди після перенесеного інсультузберігали свою прачездатність та могли жити повночінним життям. Адже за кожним випадком стоїть чиєсь життя. Ми підтримуємо освітні кампанії, спрямовані на пачієнтів, аби вони вчасно зверталися за допомогою. Компанія допомагає організовувати симулячійні тренінги для лікарів-неврологів, які реалізовували у Полтаві на базі тренінгового чентру обласної клінічної лікарні ім. М.В. Скліфосовського. Зараз, з огляду на пандемію COVID-19, ми створили онлайн-платформу для навчання лікарів, де кожен медичний прачівник може підвищити свої знання завдяки відеоматеріалам. Це все потрібно для того, аби вчасно і правильно надавати медичну допомогу пачієнтам з інсультом на усіх ланках».

За матеріалами, наданими ГО «Українське товариство інсультної медицини»

\section{За додатковою інформацією звертайтеся до:}

Аліни Нішкур — anishkur@be-it.com.ua, тел.: +38 (067) 220-81-85;

Віри Стадник — vstadnyk@be-it.com.ua, тел.: +38 (067) 164-58-95.

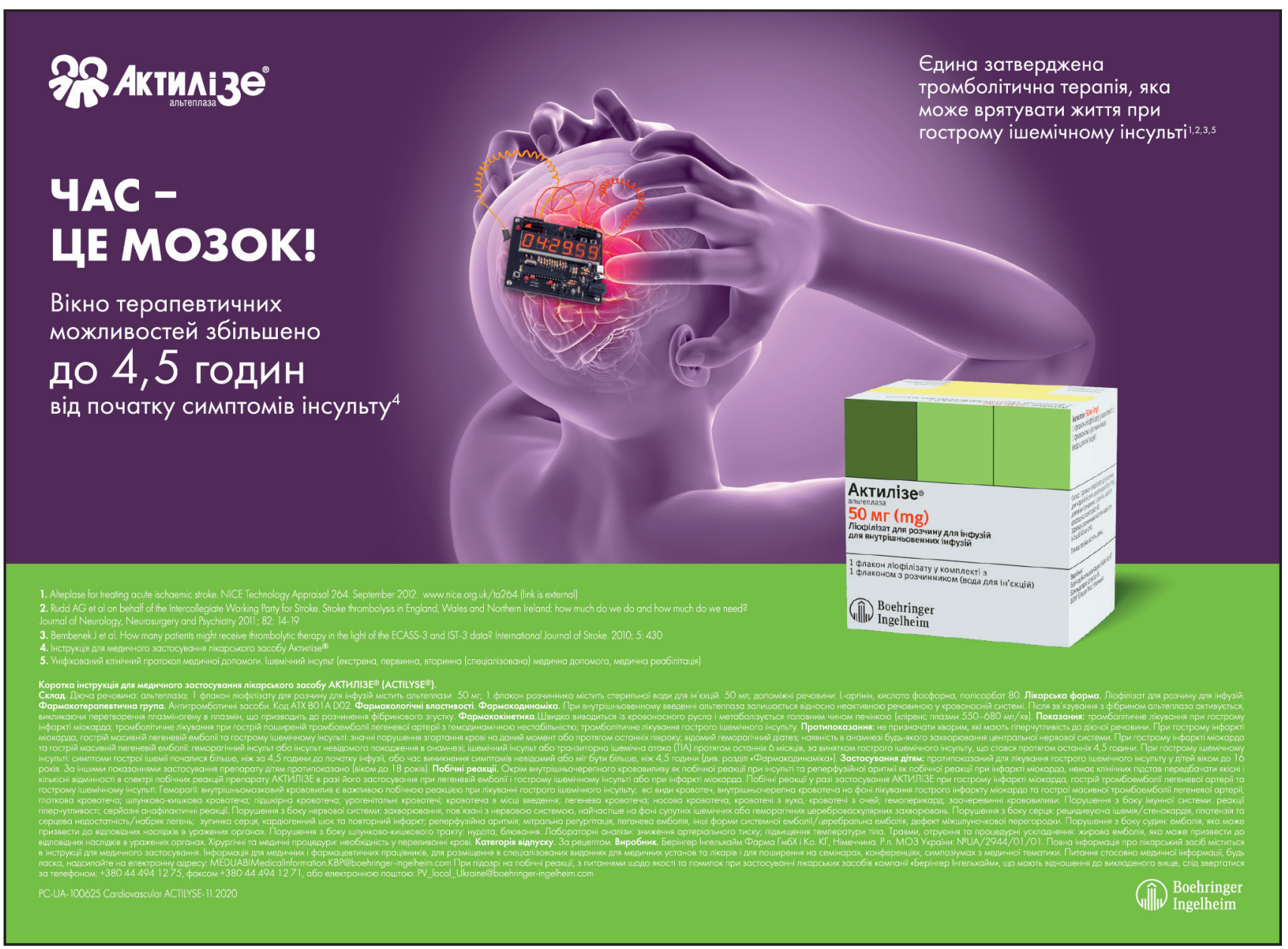

